\title{
An integrated airborne gravity survey of an offshore area near the northern Noto Peninsula, Japan*
}

\author{
Masao Komazawa ${ }^{1,3}$ Shigeo Okuma ${ }^{1}$ Jiro Segawa $^{2}$ \\ ${ }^{1}$ Geological Survey of Japan, AIST, Central 7, 1-1-1 Higashi, Tsukuba, Ibaraki 305-8657, Japan. \\ ${ }^{2}$ Tokyo University of Marine Science and Technology, 5-32-7 Minamidaira, Hino, Tokyo 191-0041, Japan. \\ ${ }^{3}$ Corresponding author. Email: komazawa-m@aist.go.jp
}

\begin{abstract}
An airborne gravity survey using a helicopter was carried out in October 2008, offshore along the northern Noto Peninsula, to understand the shallow and regional underground structure. Eleven flight lines, including three tie lines, were arranged at $2 \mathrm{~km}$ spacing within $20 \mathrm{~km}$ of the coast. The total length of the flight lines was $\sim 700 \mathrm{~km}$. The Bouguer anomalies computed from the airborne gravimetry are consistent with those computed from land and shipborne gravimetry, which gradually decrease in the offshore direction. So, the accuracy of the airborne system is considered to be adequate. A local gravity low in Wajima Bay, which was already known from seafloor gravimetry, was also observed. This suggests that the airborne system has a structural resolution of $\sim 2 \mathrm{~km}$.

Reduction of gravity data to a common datum was conducted by compiling the three kinds of gravity data, from airborne, shipborne, and land surveys. In the present study, we have used a solid angle numerical integration method and an iteration method. We finally calculated the gravity anomalies at $300 \mathrm{~m}$ above sea level. We needed to add corrections of $2-5 \mathrm{mGals}$ in order to compile the airborne and shipborne gravity data smoothly, so the accuracy of the Bouguer anomaly map is considered to be nearly $2 \mathrm{mGal}$ on the whole, and $5 \mathrm{mGals}$ at worst in limited or local areas.
\end{abstract}

Key words: airborne gravity survey, Bouguer anomalies, graben, Noto Peninsula, shipborne gravity survey, reduction to datum level.

\section{Introduction}

The aim of this investigation is to understand shallow underground structures, including the distribution of buried active faults in the eastern region of the epicentral area of the 2007 Noto-Hanto earthquake, which occurred in March 2007. As many kinds of survey, including seismic surveys and geological surveys, had been conducted around the epicentral region and detailed structure was already obtained, the eastern region of the epicentral area was selected. As one of the investigation methods, an airborne gravity survey using a helicopter was carried out over the northern coastal region of the Noto Peninsula for 3 days, starting 7 October 2008. Airborne gravimetry, as compared with shipborne gravimetry, enables us to conduct a regional survey quickly, and it is easy to make a gravity anomaly map in a short period of time. The airborne gravity survey was also conducted to compare its accuracy with shipborne, seafloor, and ordinary land gravity surveys. A shipborne gravity survey had been conducted in 1988, and land gravity surveys were conducted in 1982, 2006, and 2008. The shipborne and land data measured by 1988 were compiled to make the Bouguer anomaly map of Japan, and were published in 2000 (Geological Survey of Japan, 2000). The land and seafloor data measured in 2006 and 2008 are published in 2010 (Komazawa and Okuma, 2010).

According to the results of land and shipborne gravity surveys in this area, it appears that the gravity field has remarkable and steep gradients several kilometres offshore.

\section{Survey area}

The survey area for the airborne gravimetry was $\sim 20 \mathrm{~km}$ by $60 \mathrm{~km}$ $\left(\sim 1200 \mathrm{~km}^{2}\right)$ along the northern coastline of the Noto Peninsula. The survey area is mainly marine, with land areas including the northern Noto Peninsula and Nanatsu Island offshore. Flight lines are shown in Figure 1. The main flight lines are arranged at intervals of $\sim 2 \mathrm{~km}$ parallel to the coastline, and three tie lines are arranged with intervals of $\sim 20 \mathrm{~km}$. The total track length is $\sim 700 \mathrm{~km}$. The epicentre of the 2007 Noto-Hanto earthquake is marked with black star.

\section{Airborne gravimeter system}

The Segawa airborne gravity measurement system (Segawa et al., 2000) was adopted for this survey. The development of the Segawa-Tokimec Model FGA-1 system was completed in 1999. The gravimeter system and two kinds of GPS systems were mounted on a Bell412 (JA9616) helicopter, with a crew composed of two pilots, two observation operators, and one navigator. The gravimeter system records gravity acceleration and helicopter position/speed data. The vertical and horizontal acceleration of the helicopter are obtained from the change of helicopter altitude and location from the interferometric GPS positioning data, which has $1 \mathrm{~cm}$ accuracy. The speed and the position of the helicopter give the Eötvös effect. The GPS

\footnotetext{
*Part of this paper was presented at the 9th SEGJ International Symposium (2009).
} 


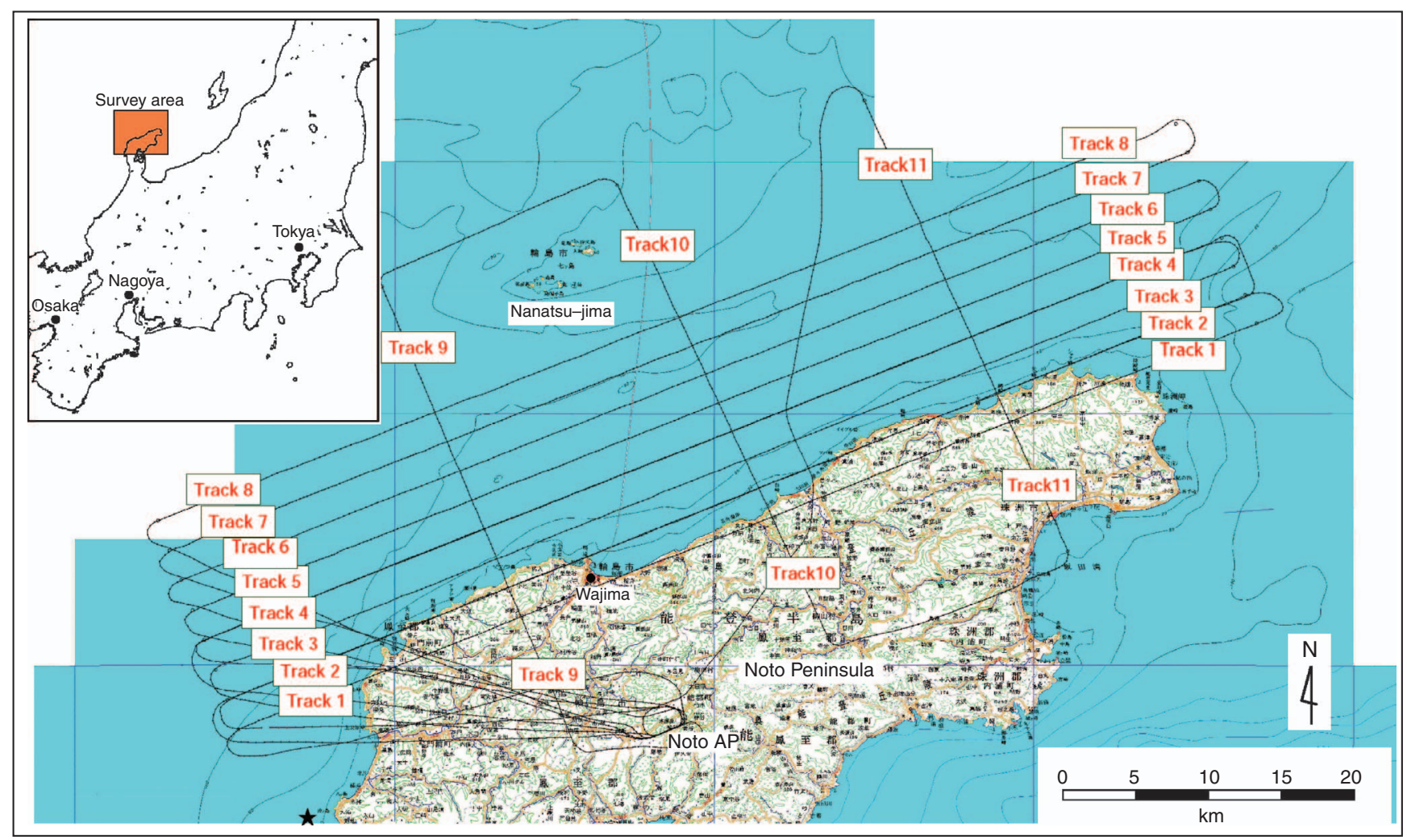

Fig. 1. Flight line map. TRK denotes track. Flight altitude of Track 1, 2, 9, 10 was $2000 \mathrm{ft}$. Flight altitude of Track 3, 4, 5, 6, 7 and 8 was $1000 \mathrm{ft}$. In addition, Tracks 2 and 4 were also repeated at $3000 \mathrm{ft}$ altitude, to examine the upward continuation effect, vertical gradient variation of gravity, and reproducibility. The star denotes the epicentre of the 2007 Noto-Hanto earthquake.

positioning data are also used for the calculation of Normal Gravity or latitude effect and the free-air correction.

\section{Gravity measurement}

The apron of the Japan Aviation College of the Japan Aviation Academy, adjoining the Noto airport, in Wajima city, Ishikawa prefecture, was used as a heliport, and a gravity base station was established there. The absolute gravity of the base station was determined by a gravimetric tie between the base station and the Japan Gravity Standardization Net 1975.

The acceleration of the helicopter was sampled at $100 \mathrm{~Hz}$ to reduce the influence of high frequency vibration as much as possible, and gyroscope and GPS measurements were taken every second. The turbulence accelerations in the helicopter motion reach 100 galG $(1 \mathrm{gal}=0.01 \mathrm{~m} / \mathrm{s})$ and the measurement aims at $1 \mathrm{mGal}$ accuracy, so that the signal-to-noise ratio is $1: 100000$. A digital filter performs noise reduction; a Hamming Window

Helicopter gravity survey (2nd Flight on 7th Oct, 2008)-form 3

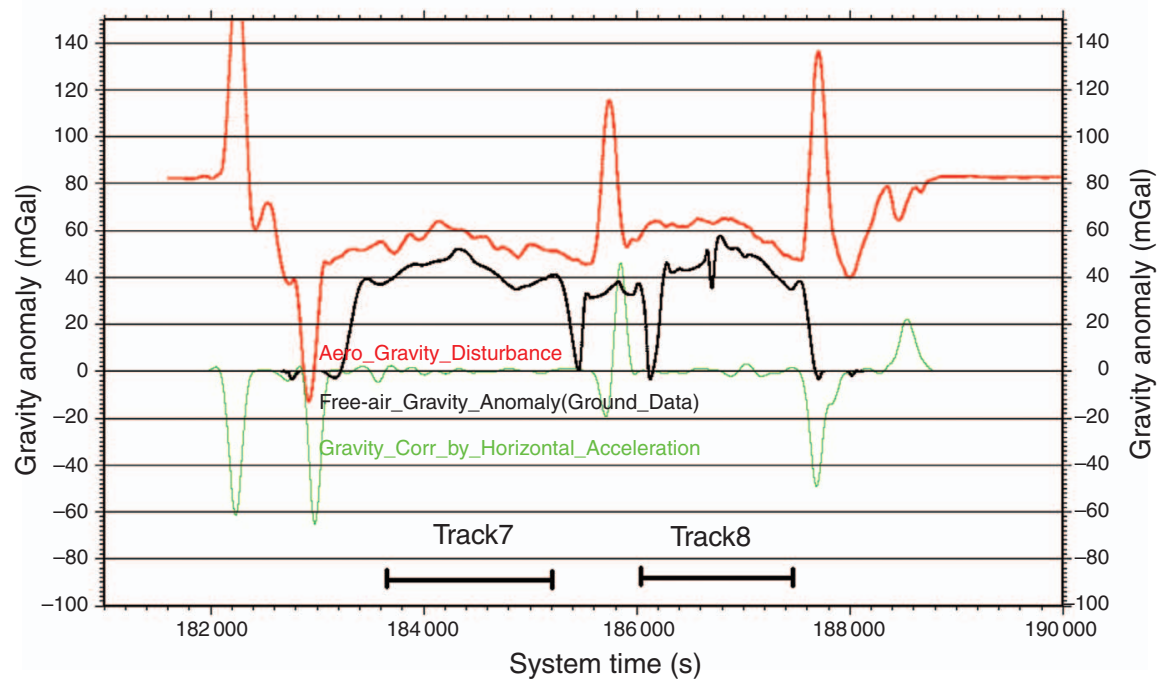

Fig. 2. Results of Tracks 7 and 8 compared with ground truth shipborne gravimetry. The height recorded in the airborne gravimetry is GPS-based ellipsoidal height, so the gravity anomaly computed is a gravity disturbance, not a free-air anomaly. 
with a time constant of $150 \mathrm{~s}$ was used in this system. Based on a half wavelength with this filter, the resolution is $\sim 1.5 \mathrm{~km}$ at the typical speed of the helicopter of $60 \mathrm{~km}$. Even if the high frequency noise can be removed with the filter, flight altitude may change gently, so there may still be a low frequency trend. The vertical gradient of normal gravity is $0.3086 \mathrm{mGal} / \mathrm{m}$ up to around $1000 \mathrm{~m}$ height. The altitude obtained by GPS is not the height above sea level but the ellipsoidal height. If the free-air reduction is performed using the ellipsoidal height, the resulting gravity anomaly is not the free-air anomaly but the gravity disturbance. The height above sea level is obtained from the difference between the ellipsoidal height given by GPS and the geoid height, given by the geoid model. The free-air anomaly can then be calculated from the free-air correction using the height above sea level. The WGS 84 geodetic system is adopted for this survey.

Gravity measurements were performed during the period from 7 to 9 October 2008, after a preparation period between
1 and 6 October 2008. Six gravity measurement flights, covering 11 tracks, are shown in Figure 1. Because changes in flight altitude influence gravity acceleration, each flight was at a fixed altitude as far as possible. Geographic and weather conditions were taken into consideration for every flight, and the altitude was fixed at levels between $1000 \mathrm{ft}$ and $3000 \mathrm{ft}$. Tracks 1, 2, 9, 10, and 11, which included over-land flights, were flown at $2000 \mathrm{ft}$. Tracks 3 , $4,5,6,7$, and 8 over the sea were flown at $1000 \mathrm{ft}$, to determine detailed structure. In addition, Tracks 2 and 4 were flown at $3000 \mathrm{ft}$ to examine the upward continuation, vertical gravity gradient variation, and reproducibility.

Shipborne and land gravity data was taken as ground truth, to verify the accuracy of the airborne gravity data. The data from Tracks 7 and 8 on the northern side of the area are shown in Figure 2, where a high density of shipborne gravity data is available. Using the geoid model EGM96, the geoid height in this area is 37.1 to $37.8 \mathrm{~m}$, so the difference between the gravity disturbance and the free-air anomaly is $\sim 11.5$ mGals. If this is

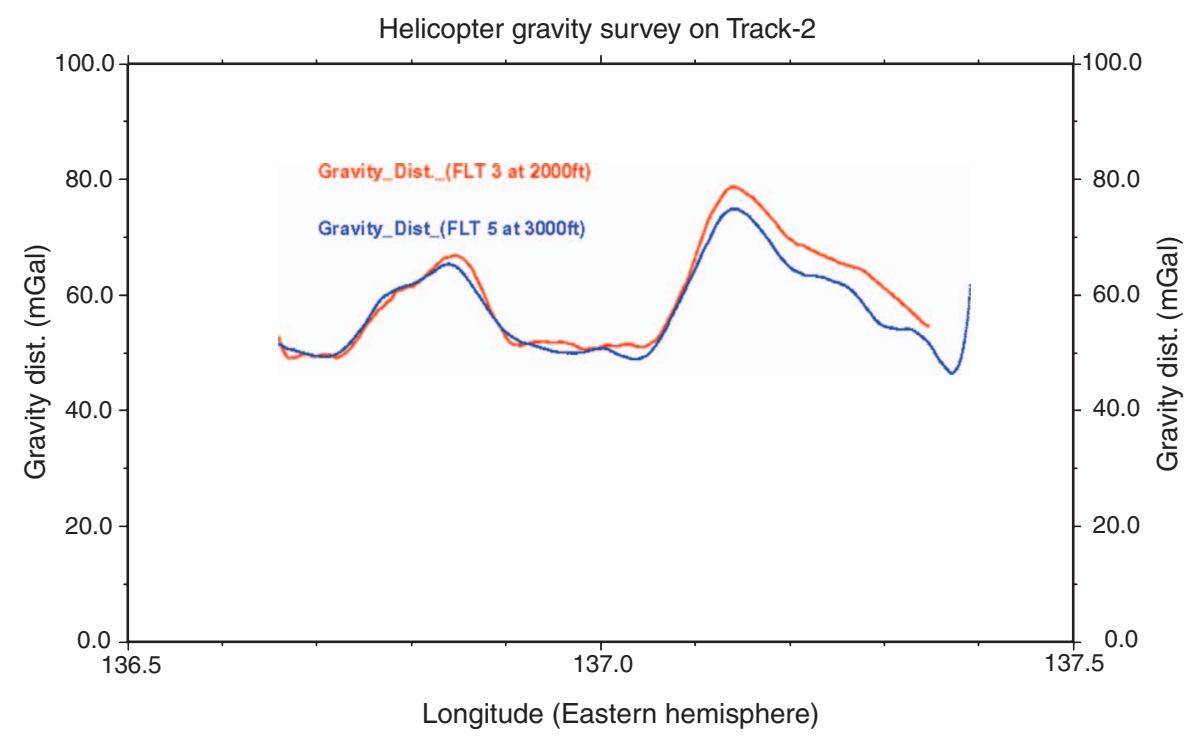

Fig. 3. Gravity disturbances at different altitudes on Track 2. Red curve denotes the gravity disturbance at $2000 \mathrm{ft}$. Blue curve denotes the gravity disturbance at $3000 \mathrm{ft}$.

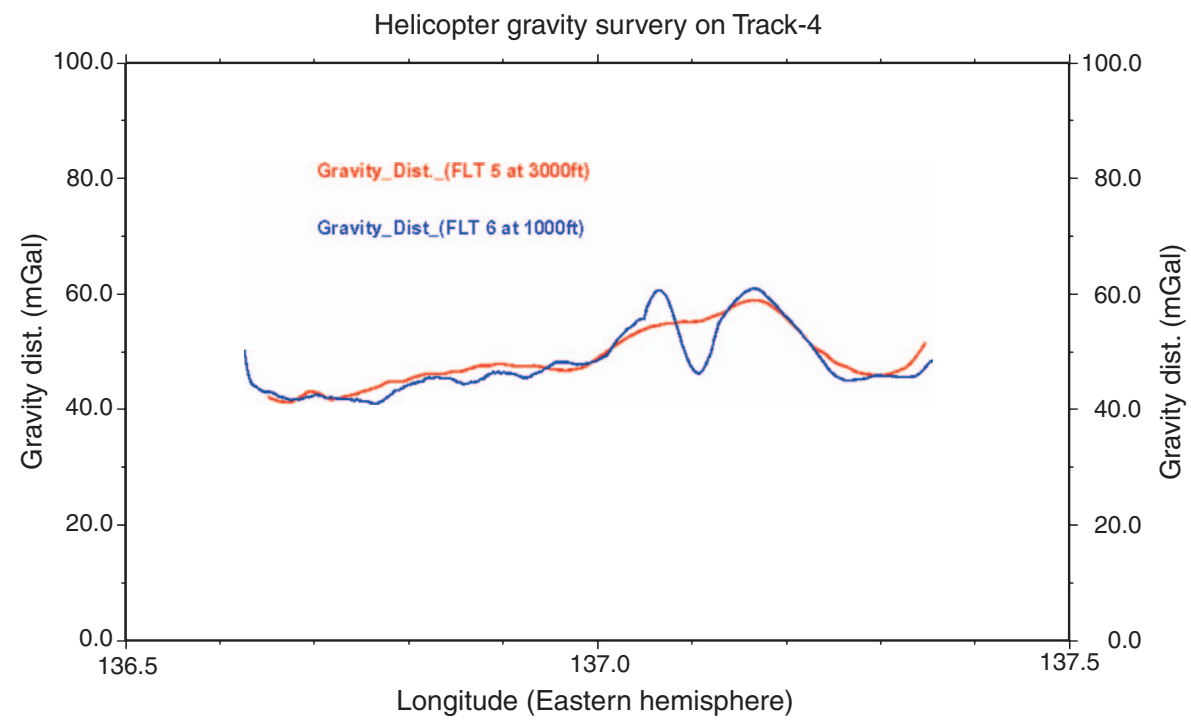

Fig. 4. Gravity disturbances at different altitudes on Track 4. Blue curve denotes the gravity disturbance at $1000 \mathrm{ft}$. Red curve denotes the gravity disturbance at $3000 \mathrm{ft}$. 
taken into consideration, the airborne and shipborne gravity data become conformable with each other.

Repeated-measurements at different altitudes were performed on Tracks 2 and 4, and the accuracy of this airborne gravity measurement system was evaluated from the reproducibility of the data. Comparing flights at $2000 \mathrm{ft}$ and $3000 \mathrm{ft}$ on Track 2 (Figure 3) shows that the difference in the short-wavelength pattern is small, because the altitude difference is small. However, the values at $3000 \mathrm{ft}$ are smaller on the eastern half where there is a comparatively large-scale high-gravity region, because the high gravity values decrease as altitudes increase regionally. In Figure 4 for Track 4, the altitudes are $1000 \mathrm{ft}$ and $3000 \mathrm{ft}$; the large altitude difference makes the short-wavelength pattern at $3000 \mathrm{ft}$ smaller and smoother.

\section{Data processing of airborne gravity data for Bouguer anomalies}

The observed airborne gravity data were all referenced to the International Gravity Standardization Net 1971 (JGSN75 in Japan), and normal gravity was calculated using the Gravity Formula 1980 from the Geodetic Reference System 1980. In order to compare with land or shipborne gravity data, the gravity disturbances provisionally obtained from the airborne gravity data were changed into Bouguer anomalies. If the GPS-based ellipsoidal height of a measurement point is transformed to the geoid-based height, the free-air anomaly or Bouguer anomaly can be obtained from the gravity disturbances. It is common in Japan to use the GSIGEO2000 geoid model, supplied by the Geographical Survey Institute, but this model does not cover this sea area. Instead, for this work, the EGM96 geoid model was adopted. This model was published jointly by the United States National Aeronautical and Space Agency and the National Imagery and Mapping Agency in 1998 and is currently used for general-purpose of GPS analysis (US NASA and NIMA, 1998). The geoid height at the Noto airport is set as $37.55 \mathrm{~m}$ by GSIGEO2000 of the Geographical Survey Institute (Kuroishi et al., 2002), and $37.40 \mathrm{~m}$ by EGM96. The difference is only

\section{Airborne gravity observation}

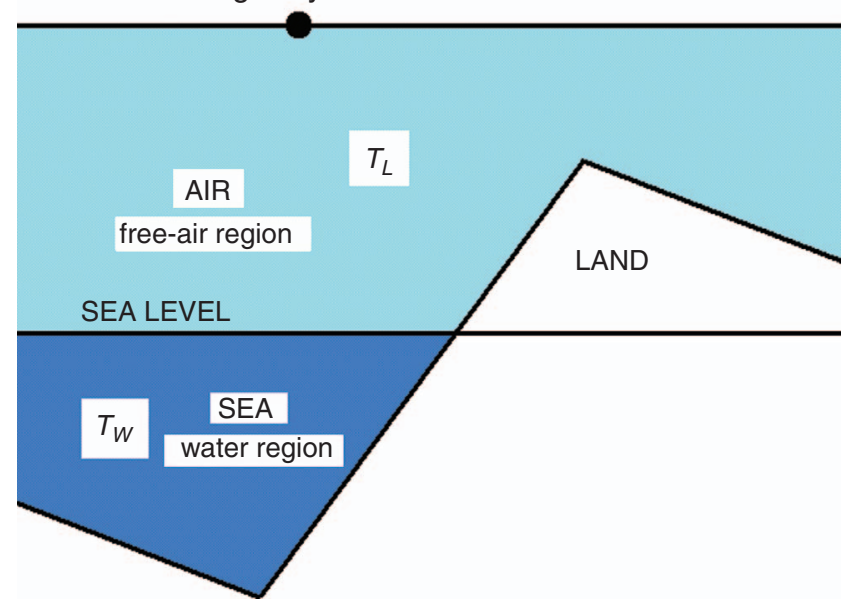

Fig. 5. Diagram of terrain correction of airborne gravity data. $T_{L}$ is the unitdensity terrain correction of the free-air region between the observation level and the surface of land or sea. $T_{W}$ is the unit-density terrain correction of the water region.

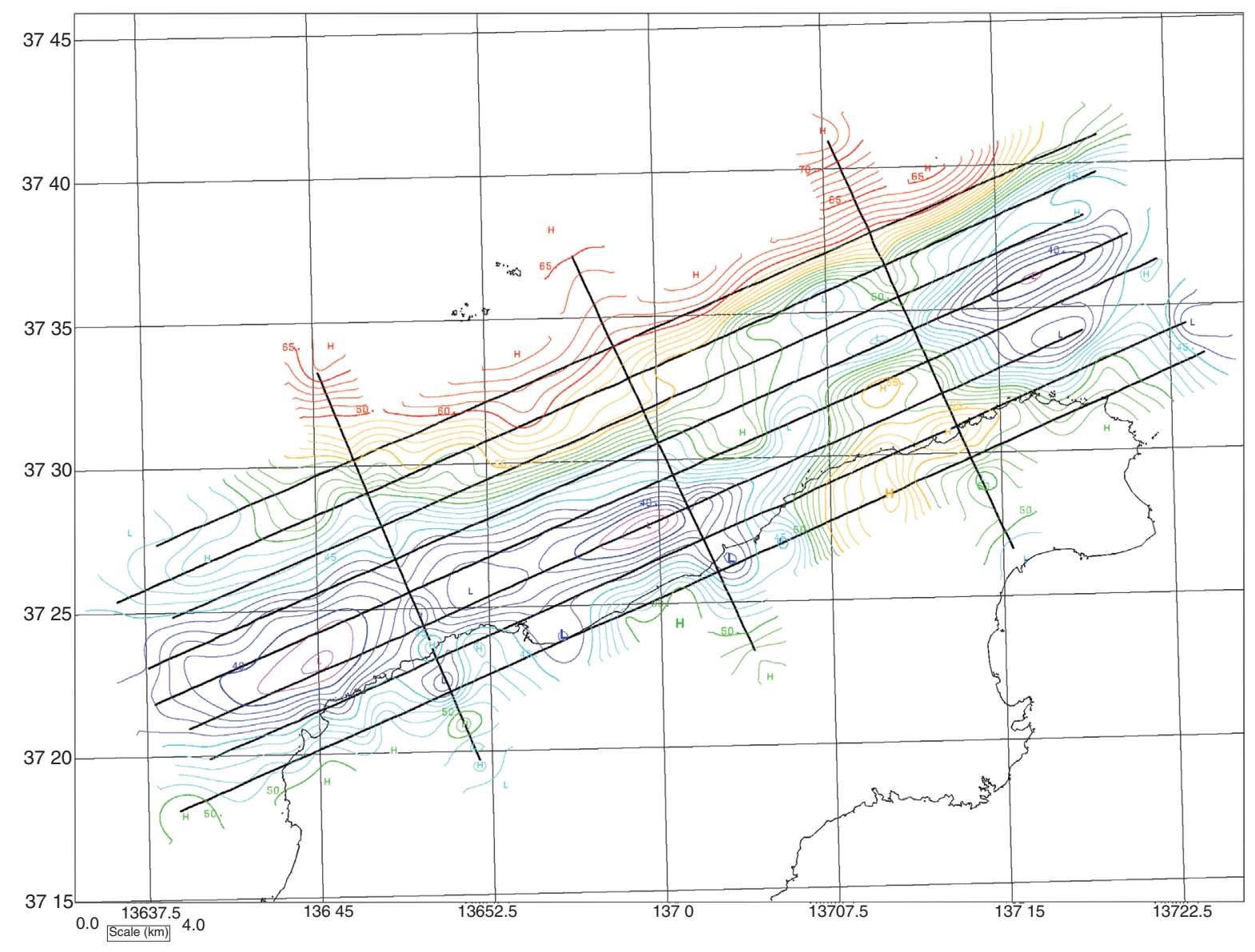

Fig. 6. Bouguer anomalies from airborne gravity data. Assumed density is $2400 \mathrm{~kg} / \mathrm{m}^{3}$. Contour interval is $1 \mathrm{mGal}$. Black lines are composed of dots that mark airborne gravity measurement points. 
$0.15 \mathrm{~m}$, and it will be considered to be unimportant for the present purpose of comparing Bouguer anomalies.

The formula for the Bouguer anomaly $\Delta g_{0}$ ' is

$$
\Delta g_{0}^{\prime \prime}=g-\gamma+(\beta-2 \pi G \rho) h+T(\rho)+C_{A},
$$

where

$$
T(\rho)=\rho \cdot T_{L}+\left(\rho-\rho_{W}\right) \cdot T_{W},
$$

$g, \gamma, \beta(0.3086 \mathrm{mGal} / \mathrm{m}), \rho, G\left(6.6730 \times 10^{-11} \mathrm{~m}^{3} \cdot \mathrm{kg}^{-1} \cdot \mathrm{s}^{-2}\right), C_{A}$, and $h$ are the total terrain correction, the observed absolute gravity, normal gravity, normal gravity gradient, assumed density, universal gravity constant, air correction and height above sea level, respectively.

Equation 2 calculates the total terrain correction with the assumed density $\rho$, and this correction is shown in Figure 5. The $\rho_{W}$ is the density of water. $T_{L}$ is the unit-density terrain correction for the free-air region between the observation point and the surface of land or sea. The $T_{W}$ is the unit-density terrain correction for the water region.

Terrain corrections were calculated within a range of $60 \mathrm{~km}$ by approximating the actual topography with an assemblage of prisms based on digital elevation model (DEM) mesh data. The DEM for terrain corrections is presented as a mesh of values above sea level. The DEM for terrain corrections was made by revising the terrain data in the ' $50 \mathrm{~m}$ DEM' ( $50 \mathrm{~m}$ by $50 \mathrm{~m}$ mesh), provided by the Geographical Survey Institute, and the bathymetry mesh data in the 'JEGG500 DEM' ( 500 m by $500 \mathrm{~m}$ mesh) provided by the Hydrographic and Oceanographic Department, Japan Coast Guard. The spherical effect on gravity of the topography due to the earth's curvature was taken into consideration. Bouguer corrections within a range of $60 \mathrm{~km}$ were performed with a spherical cap formula. For further details see Komazawa (1988).

In equation 1, although a free-air correction is included in this processing, this is not strictly a reduction of the observations to sea level based on potential theory. The resulting Bouguer anomaly is the value at the measuring point, not the value at sea level.

\section{Results of survey}

The airborne gravity Bouguer anomalies, for an assumed density of $2400 \mathrm{~kg} / \mathrm{m}^{3}$, were gridded and contoured and are shown in Figure 6 . The gridded values were interpolated by fitting $2 \mathrm{D}$ quadratic polynomials with distance-dependent weights to the local surface observed values. Measurements at different altitudes were conducted on Tracks 2 and 4 . However, the data from $3000 \mathrm{ft}$ altitude were not compiled because it is impossible to compile values observed at different elevations, even at the same horizontal point on the same track. For comparison, the Bouguer anomalies compiled from shipborne and land gravity data are shown in Figure 7.

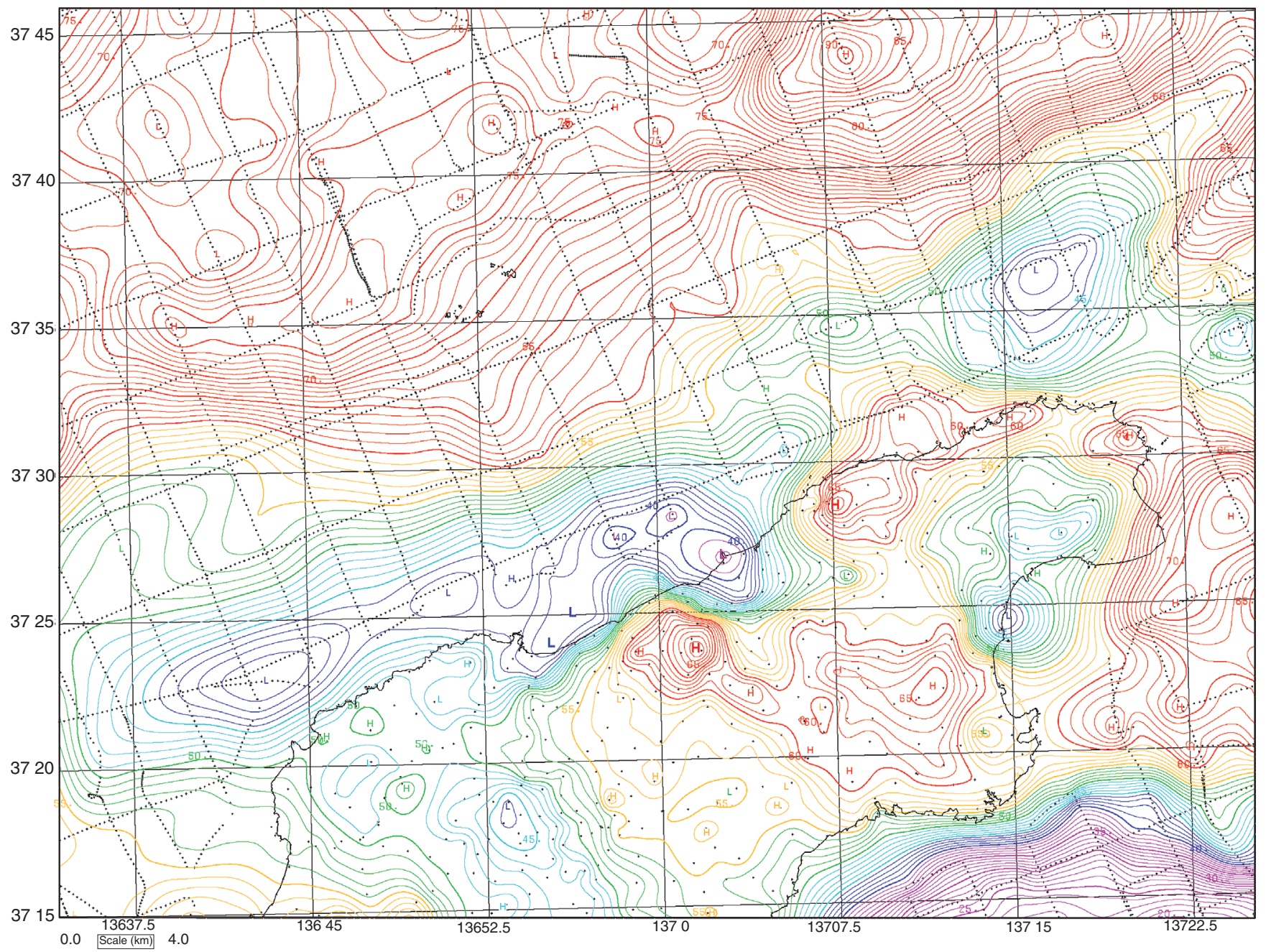

Fig. 7. Bouguer anomalies from shipborne and land gravity data. Assumed density is $2400 \mathrm{~kg} / \mathrm{m}^{3}$. Contour interval is $1 \mathrm{mGal}$. Black dots denote gravity measurement points. 
In Figure 6, the result obtained shows that the detailed structure with a wavelength of $\sim 2 \mathrm{~km}$ is clearly extracted. The low gravity belt was detected, with a width of $\sim 4 \mathrm{~km}$, extending from east-north-east to west-south-west between 2 and $4 \mathrm{~km}$ off the western half of the Noto Peninsula northern coast, and may correspond to a syncline structure. Although a similar low gravity belt is detected by shipborne gravity, the minimum is shifted a little to the north. The reason is that the survey vessel, Hakureimaru, is $3 \mathrm{~km}$ or more away from the coast when the measurement was carried out.

One flight line for airborne gravity was taken along the coast so a steep gravity gradient $\sim 1 \mathrm{~km}$ offshore was also detected. A low gravity region with a diameter of $\sim 2 \mathrm{~km}$ exists in Wajima Bay and $\sim 10 \mathrm{~km}$ east and the same patterns appear in Figure 7. Although the two high gravity regions on land, located $\sim 8 \mathrm{~km}$ and $25 \mathrm{~km}$ east of Wajima, are detected on Track 1, the values from airborne gravity are $\sim 5 \mathrm{mGals}$ smaller than those from land gravity. This might be explained by the upward continuation effect. The low gravity regions and the high gravity region mentioned above are marked by bigger character ' $\mathrm{L}$ ' and ' $\mathrm{H}$ ' in Figures 6 and 7 .

\section{Gravity reduction to a common datum level and compilation}

A reduction of gravity data to a common datum level was conducted in order to combine three kinds of gravity data, from airborne, shipborne and land surveys.
First, we assumed condensation gravity anomalies at a condensation level, i.e. sea level, and calculated gravity anomalies at measurement points (refer to Figure 8). For fast and effective calculation, we used the solid angle numerical integration method and the iteration method. We set the initial values of the condensation gravity anomalies to be equal to

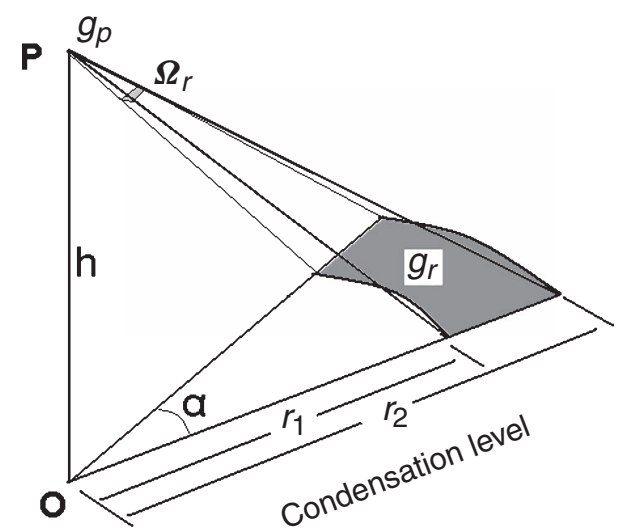

Fig. 8. Diagram of gravity reduction processing. $h, r_{1}, r_{2}$ and $\alpha$ are height, radius of inner circle, radius of outer circle and central angle, respectively. The gravity anomaly $g_{p}$ is calculated from the condensation anomaly $g_{r}$ and the solid angle $\Omega$

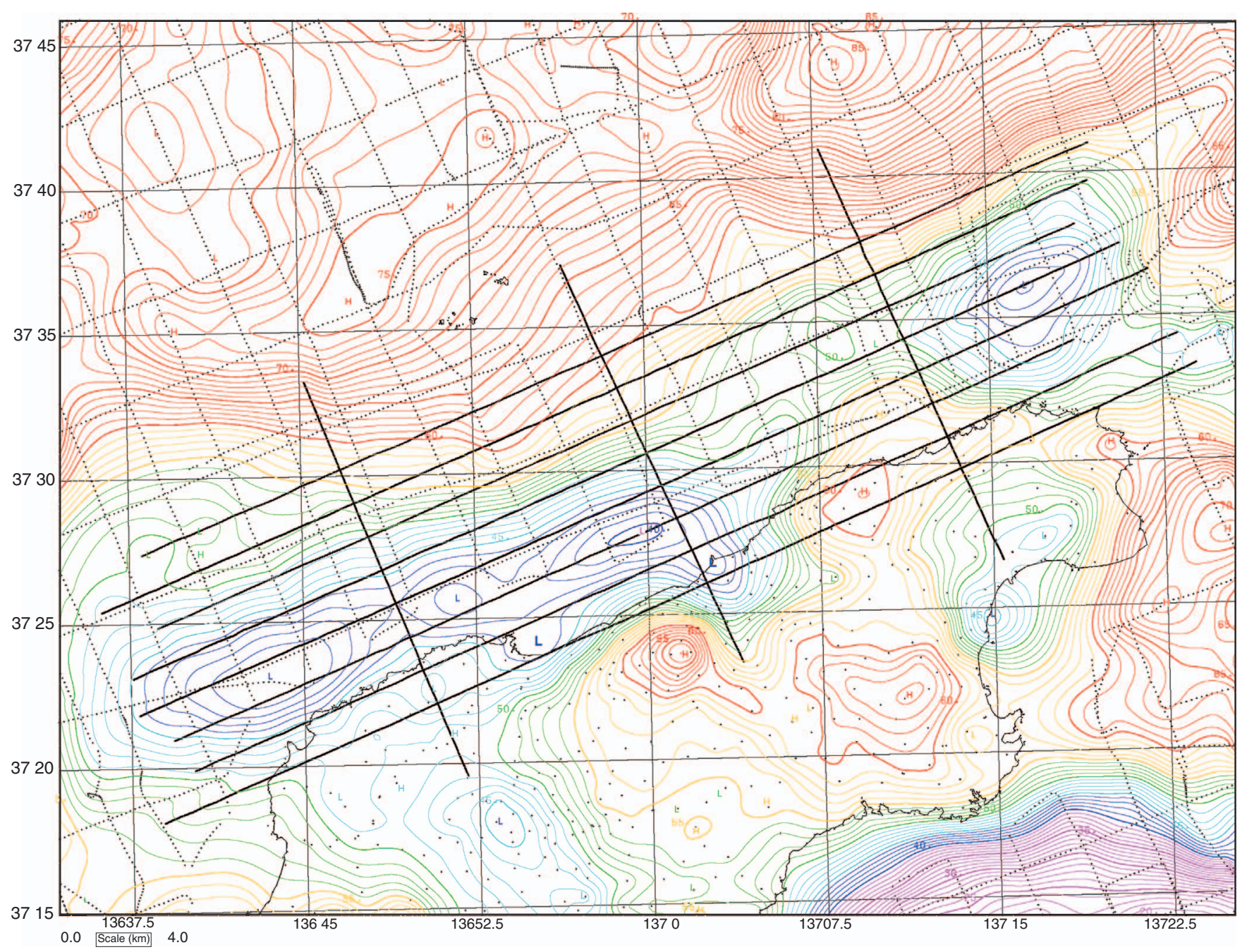

Fig. 9. Bouguer anomalies at $300 \mathrm{~m}$ above sea level from the compilation of airborne, shipborne, and land gravity data. Assumed density is $2400 \mathrm{~kg} / \mathrm{m}^{3}$. Contour interval is $1 \mathrm{mGal}$. 
the observed Bouguer anomalies with the same horizontal coordinates. The solid angle $\Omega_{r}$ is calculated by equation 3:

$$
\Omega_{r}=\alpha h\left(1 / \sqrt{h^{2}+r_{1}^{2}}-1 / \sqrt{h^{2}+r_{2}^{2}}\right),
$$

where $h, r_{1}, r_{2}$ and $\alpha$ are height, radius of inner circle, radius of outer circle and central angle, respectively. The gravity anomaly $g_{p}$ is calculated from the condensation gravity anomalies $g_{r}$ and the solid angle $\Omega_{r}$ by equation 4 :

$$
g_{p}=\sum_{r} g_{r} \Omega_{r} / \sum_{r} \Omega_{r}
$$

where

$$
\sum_{r} \Omega_{r}=2 \pi .(5)
$$

Second, the condensation anomaly $g_{r}$ at any point for equation 4 is calculated by interpolation from observation points, as described earlier, because the condensation gravity anomalies may not necessarily be grid values. Third, we correct the condensation gravity anomaly $g_{r}$ by iteratively checking differences between the calculated anomalies and the observed Bouguer anomalies at the measurement points. Tsuboi (1965) called the reduction gravity anomalies at sea level the 'real Bouguer anomalies' and the gravity anomalies at measurement points 'station Bouguer anomalies'. Finally, the gravity anomalies at $300 \mathrm{~m}$ above sea level, which is higher than the highest level of topography, i.e. the the maximum level of the density distribution, are computed by equation 4 from the condensation gravity anomalies at sea level, and are shown in Figure 9. This gravity reduction processing is the same as an upward continuation from the condensation level at $0 \mathrm{~m}$ to the datum level at $300 \mathrm{~m}$. We had to add correction values of 2-5 mGals in order to combine the airborne and shipborne gravity data smoothly, so the accuracy of Figure 9 is considered to be nearly $2 \mathrm{mGal}$ on the whole, and $5 \mathrm{mGals}$ at worst in limited or local areas.

Two isolated low gravity regions shown in Figures 6 or 7 , in Wajima Bay and $\sim 10 \mathrm{~km}$ east of Wajima, are connected smoothly in the final gravity reduction, and the low gravity belt corresponding to a syncline becomes clear in Figure 9. The two low gravity regions might correspond to small-scale depressions branching from the syncline.

\section{Conclusions}

Because the shipborne gravimetry is conducted on the sea surface there are some problems. For example, it is hard to take measurements close to land. However, for airborne gravimetry, it is easy to plan flight lines anywhere, except for geographical restrictions. Therefore, a survey along the coast could be set up freely. Moreover, the survey duration is very short compared with shipborne gravimetry, so drift of the gravimeter is expected to be small.

The Eötvös effect is large because of the high speed of the airborne gravity platform, as in this case. The survey was conducted at $60 \mathrm{~km}$, instead of at $90 \mathrm{~km}$ as in a previous survey, to reduce the Eötvös effect, which is thought to be somewhat effective. A flight line spacing of $2 \mathrm{~km}$ was adopted, which is about half of the track interval of the previous survey, so that short wavelength structures could be detected.

From the reduction of gravity anomalies to a common datum level, it was found that the error of this airborne system is less than $5 \mathrm{mGal}$.

\section{Acknowledgments}

The authors thank the Japan Aviation College of the Japan Aviation Academy, Noto Airport Office and Japan Air Self-Defence Force for their cooperation on this survey. The authors thank two anonymous reviewers for valuable comments, and Dr Lindsay Thomas of Australian Society of Exploration Geophysicists for his specific reading and valuable comments.

\section{References}

Geological Survey of Japan, 2000, Gravity CD-ROM of Japan, Digital Geoscience Map P-2: Geological Survey of Japan.

Komazawa, M., 1988, A gravimetric terrain correction method by assuming annular prism model: Journal of Geodesy Society of Japan, 34, 11-23. [in Japanese with English abstract]

Komazawa, M., and Okuma, S., 2010, $1: 200,000$ Gravity map in and around the northern part of Noto Peninsula, with explanatory note, In: Seamless Geoinformation of coastal zone, "Northern coastal zone of Noto Peninsula" Digital Geological Map S-1: Geological Survey of Japan, AIST.

Kuroishi, Y., Ando, H., and Fukuda, Y., 2002, A new hybrid geoid model for Japan, GSIGEO2000: Journal of Geodesy, 76, 428-436. doi:10.1007/ s00190-002-0266-5

Segawa, J., Kusumoto, S., Joseph, E. J., Hasegawa, H., Sekizaki, S., Takada, C., Nakayama, E., Suzuki, H., Ishihara, T., Komazawa, M., Yamamoto, K., and Sakuma, S., 2000, Airborne Gravity Measurement System by use of a Helicopter: Journal of Geodesy Society of Japan, 46, 223-229. [in Japanese with English abstract]

Tsuboi, C., 1965, Calculation of Bouguer anomalies with due regard to the anomaly in the vertical gravity gradient: Proceedings of Japanese Academy of Science, 41, 386-391.

US NASA and NIMA, 1998, United States National Aeronautical and Space Agency and National Imagery and Mapping Agency EGM96/ The NASA GSFS and NIMA Joint Geopotential Model. Available online at: http://cddisa.gsfc.nasa.gov/926/egm96/getit.html (accessed 2 January, 2010)

Manuscript received 10 September 2009; accepted 25 December 2009. 


\section{能登半島北部沖における空中重力調査}

\section{駒澤正夫 ${ }^{1} \cdot$ 大熊茂雄 $^{1} \cdot$ 瀬川爾朗 $^{2}$}

1 産業技術総合研究所 地質情報研究部門

2 東京海洋大学

要 旨： 能登半島北部沖で浅部地下構造を広域的に把握するため 2008 年 10 月にヘリコプターを使った空中重力調査を行 った。測定測線は海岸線に沿った東北東-西南西方向に 8 本、交差測線を 3 本取り、ほぼ $2 \mathrm{~km}$ 間隔で沖合 $20 \mathrm{~km}$ までに配置し た。総測線長は約 $700 \mathrm{~km}$ である。調查結果は、陸側から沖合に向かって重力異常が減ずるなど陸上及び船上重力データとも 整合するもので精度が確保されていることが定性的に判った。また、海底重力調査から判明した輪島湾の低重力異常などの局 所的な構造も見出され $2 \mathrm{~km}$ 程度の構造分解能を持つことも判った。空中、船上及び陸上の 3 種類の重力データを統一した方 法で編集してブーゲー異常図を作成した。手法としては、化成面（第一化成面として海水準を設定）の重力值と計算点から化 成面上に作る扇形を見込む立体角を重みとする加重平均を計算点の重力值とする方法によった。最終的に陸上の最高高度と海 上での飛行高度に近い標高 $300 \mathrm{~m}$ の基準面（第二化成面）に上方接続して統一した編集ブーゲー異常図を作成した。第一化成 面の重力值は反復修正法で求めたが、空中重力データは誤差を勘案して $5 \mathrm{mGal}$ までの融通性を持たせたが、それを超える誤 差はなく数 $\mathrm{mGal}$ 以内の精度が確保されていることも定量的に判った。

キーワード : 空中重力調査, 船上重力調査, 能登半島, ブーゲー異常, 盆状構造, 重力異常の基準面化成

\section{일본 노토 반도 북쪽 연안의 복합 항공 중력탐사}

Masao Komazawa ${ }^{1}$, Shigeo Okuma ${ }^{1}$, Jiro Segawa ${ }^{2}$

1 산업기술종합연구소 지질정보연구부문

2 동경해양대학

요 약: 천부와 광역적인 지체 구조를 해석하기 위하여 일본 혼슈섬 중부에 위치한 노토 반도 연안을 따라 2008년 10 월 헬리콥터를 이용한 항공 중력 탐사를 수행하였다. 항공탐사 측선은 총 $700 \mathrm{~km}$ 정도이며, 세 개의 교차측선을 포함하여 $2 \mathrm{~km}$ 간격으로 연안에서 $20 \mathrm{~km}$ 이내에서 수행되었다. 항공탐사를 통해 해석된 부게 이상은 육상탐사와 선상탐사의 결과와 잘 부합하고 있으며, 해안으로 갈수록 중력값이 감소하는 패턴 및 선행연구 결과로 알려진 와지마 만의 특성을 잘 보여주고 있어 타당성 있는 항공 탐사 결과임을 확인할 수 있었다. 이번 연구에서 제안하는 항공중력 시스템은 공간적으로 $2 \mathrm{~km}$ 정도의 해상도를 제공해 주고 있다.

항공탐사 결과를 기준면의 자료로 보정해 주기 위하여 항공, 선상, 육상 탐사 결과를 모두 이용하였으며, 이를 위하여 입체각을 이용한 수치 적분을 반복적으로 수행하였다. 최종적으로는 해발 $300 \mathrm{~m}$ 높이의 중력 이상값으로 계산하였다. 그러나, 선상중력자료와의 자연스러운 자료 통합을 수행하기 위해서는 $2-5 \mathrm{mGal}$ 정도의 추가 보정이 필요하였으며, 이를 고려하면, 이번 항공 중력 측정 자료는 $2-\mathrm{g} \mathrm{mGal}$ 의 오차 범위를 갖는 것으로 판단된다.

주요어 : 탄성파 굴절법, 천부, 해상도, 2 차원, 3 차원, $\mathrm{GRM}, \mathrm{RCS}$ 